\title{
Thermogenic drugs for the treatment of obesity: sympathetic stimulants in animal models
}

\author{
By A. G. DULLOO AND D. S. MILLER* \\ Department of Nutrition, Queen Elizabeth College, University of London, \\ Campden Hill Road, London W8 7 AH
}

(Received 5 September 1983 - Accepted 3 March 1984)

\begin{abstract}
1. Thirty-three drugs known to stimulate the sympathetic nervous system have been screened for thermogenic properties. The results presented are for seven of them.

2. The drugs were tested in five animal models of obesity (genetic (mice and rats), hypothalamic (mice) and dietary (mice and rats)) as well as in lean mice. Energy-balance studies were undertaken using the comparative-carcass technique as well as by measurement of daily oxygen consumption.

3. All seven drugs in obese animals tended to reduce body-weight and fat without loss of body protein: they acted by increasing metabolic rate without increasing food intake. They were much less effective in lean animals. These findings lend support to the concept that obesity is due to a diminished activity of the sympathetic nervous system.

4. Differences in the effectiveness of the drugs are discussed in relation to differences between the animal models of obesity. Ephedrine and tranylcypromine were found to be the most effective drugs in this series of experiments and a prima facie case is made for human clinical trials.
\end{abstract}

The methodology for screening thermogenic drugs for the treatment of obesity has been outlined by Massoudi et al. (1983) who defined an ideal drug as being one that not only increases metabolic rate and causes loss of body fat but should achieve this without a reduction in food intake or a loss of body protein. They also emphasize the need to test such drugs using obese rather than lean animals, since obesity should be regarded as a faulty homeostatic system involving a metabolic defect. At the present time, the most promising drug is ephedrine (Massoudi \& Miller, 1977; Rothwell \& Stock, 1979; Arch et al. 1982; Morgan et al. 1982; Massoudi et al. 1983). Since ephedrine may be considered to act as though it were a long-acting noradrenaline, the results of experiments with a further six sympathomimetic drugs are presented here in comparison with ephedrine as a positive control. The six new drugs were selected from preliminary screening of the thirty-three drugs shown in Table 1, which act at various sites along the line of sympathetic control. Those selected are all described in the pharmacopoeias but with applications in many fields other than obesity.

The use of thermogenic drugs in the treatment of obesity has enormous potential therapeutically but also could be of value in understanding the metabolic basis of obesity and leanness. There are three main types of animal model used in the study of the aetiology of obesity (hypothalamic, genetic and dietary) all of which have been shown to have a high efficiency of energy utilization (Miller, 1979). It is not known which is appropriate to human obesities, and it is wise therefore to use as many animal models as possible.

\section{METHODS}

Six energy-balance experiments, based on the comparative-carcass technique, were carried out to study the potential thermogenic effects of seven sympathomimetic drugs in five different obese models, and also in lean mice.

\footnotetext{
* For reprints.
} 
Table 1. Sympathomimetic agents screened for thermogenic properties

\begin{tabular}{|c|c|c|c|}
\hline $\begin{array}{l}\text { Site and mode } \\
\text { of action }\end{array}$ & Type of drug & Drug name & $\begin{array}{l}\text { Main pharmacological } \\
\text { use }\end{array}$ \\
\hline \multirow[t]{3}{*}{$\begin{array}{l}\text { Stimulation of } \\
\text { postsynaptic } \\
\text { adrenergic } \\
\text { receptors }\end{array}$} & $\begin{array}{c}\text { Non-selective } \\
\beta \text {-agonists }\end{array}$ & $\begin{array}{l}\text { Orciprenaline } \\
\text { Methoxyphenamine } \\
\text { Isoprenaline } \\
\text { Isoxsuprine }\end{array}$ & $\begin{array}{l}\text { Vasodilators used in } \\
\text { the treatment of } \\
\text { bronchial asthma }\end{array}$ \\
\hline & $\begin{array}{l}\text { Selective } \\
\beta_{2} \text {-agonists }\end{array}$ & $\begin{array}{l}\text { Salbutamol } \\
\text { Terbutaline }\end{array}$ & and bronchitis \\
\hline & $\alpha$-agonists & $\begin{array}{l}\text { Phenylephrine } \\
\text { Naphazoline } \\
\text { Xylometazoline }\end{array}$ & $\begin{array}{l}\text { Vasoconstrictor used } \\
\text { in rhinitis and } \\
\text { sinusitis }\end{array}$ \\
\hline $\begin{array}{l}\text { Stimulation of } \\
\text { NA synthesis }\end{array}$ & NA-precursors & $\begin{array}{l}\text { Tyrosine } \\
\text { Dopa } \\
\text { Dopamine }\end{array}$ & $\begin{array}{l}\text { Parkinsonism. } \\
\text { Treatment of } \\
\text { hypotension and } \\
\text { shock }\end{array}$ \\
\hline $\begin{array}{l}\text { Enhancement of } \\
\text { NA release from } \\
\text { storage sites }\end{array}$ & $\begin{array}{l}\text { NA vesicular- } \\
\text { release } \\
\text { promoters }\end{array}$ & $\begin{array}{l}\text { Ephedrine } \\
\text { Phenylpropanolamine } \\
\text { Tyramine }\end{array}$ & $\begin{array}{l}\text { Bronchospasm; as a } \\
\text { nasal decongestant }\end{array}$ \\
\hline $\begin{array}{l}\text { Blockade of } \\
\text { negative } \\
\text { feed-back } \\
\text { inhibition of } \\
\text { NA release }\end{array}$ & $\begin{array}{l}\text { Presynaptic } \\
\alpha_{2} \text {-antagonist }\end{array}$ & $\begin{array}{l}\text { Yohimbine } \\
\text { Tolazoline } \\
\text { Phenoxybenzamine }\end{array}$ & $\begin{array}{l}\text { As an antidiuretic } \\
\text { vasodilator used in } \\
\text { peripheral vascular } \\
\text { disease }\end{array}$ \\
\hline \multirow[t]{2}{*}{$\begin{array}{l}\text { Prevention of } \\
\text { enzymatic } \\
\text { inactivation } \\
\text { of NA }\end{array}$} & $\begin{array}{l}\text { Monoamine } \\
\text { oxidase } \\
(E C \text { 1 } 4.3 .4) \\
\text { inhibitors }\end{array}$ & $\begin{array}{l}\text { Tranylcypromine } \\
\text { Iproniazid } \\
\text { Pargyline } \\
\text { Phenelzine }\end{array}$ & Antidepressants \\
\hline & COMT-inhibitor & $\begin{array}{l}\text { Pyrogallol } \\
\text { Tropolone }\end{array}$ & \\
\hline \multirow[t]{2}{*}{$\begin{array}{l}\text { Prevention of } \\
\text { uptake of NA } \\
\text { from synaptic } \\
\text { junction }\end{array}$} & $\begin{array}{l}\text { Neuronal } \\
\text { NA-reuptake } \\
\text { inhibitors }\end{array}$ & $\begin{array}{l}\text { Imipramine } \\
\text { Trimipramine } \\
\text { Amitriptyline } \\
\text { Iprindole }\end{array}$ & Antidepressants \\
\hline & $\begin{array}{l}\text { Extraneuronal } \\
\text { uptake } \\
\text { inhibitor }\end{array}$ & Normetanephrine & \\
\hline $\begin{array}{l}\text { Prolongation of } \\
\text { cAMP action }\end{array}$ & $\begin{array}{l}\text { Phosphodies- } \\
\text { terase } \\
\text { (EC 3.1.4.1) } \\
\text { inhibitor }\end{array}$ & $\begin{array}{l}\text { Caffeine } \\
\text { Theophylline } \\
\text { Theobromine } \\
\text { Papaverine }\end{array}$ & $\begin{array}{l}\text { In treatment of } \\
\text { peripheral vascular } \\
\text { disease, chronic } \\
\text { bronchitis, bronchial } \\
\text { asthma and coronary } \\
\text { spasm }\end{array}$ \\
\hline
\end{tabular}

NA, noradrenaline; COMT, catechol- $O$-methyltransferase (EC 2.1.1.6). 


\begin{abstract}
Animals
Mice

These were conducted on 3-4-month-old males and lasted for 7 weeks. Three obese models and one lean strain were studied in the following experiments:

Expt 1 (MSG). Mice of the CFLP strain were made obese by chemical lesioning in the hypothalamus following injections of monosodium glutamate during the first week of life (Miller, 1979).

Expt $2(H P H F)$. Mice of the CFLP strain were made obese by feeding them a high-protein, high-fat diet (described by Miller, 1979) from weaning onwards.

Expt 3 (ob/ob). Genetically-obese mice of the $o b / o b$ strain were used.

Expt 4 (lean). Lean mice of the CFLP strain were used.
\end{abstract}

Rats

These experiments were carried out on 5-7-month-old female rats and lasted for 9 weeks. Two types of obese rats were studied in the following experiments:

Expt $5(\mathrm{fa} / \mathrm{fa})$. Obese rats of the Zucker strain were used.

Expt $6(H P H F)$. Rats were of the Hooded strain, made obese by feeding them the same energy-dense diet as in Expt 2.

\title{
Experimental procedures
}

Before the start of each experiment, the animals were given a powdered form of the stock diet (CRM, Christopher Hill Group, London) for an adaptation period of at least 2 weeks. The composition of the diet $(\mathrm{g} / \mathrm{kg})$ was: 180 protein, 24 fat, 570 carbohydrate, 36 crude fibre, $14200 \mathrm{~kJ}$ metabolizable energy $(\mathrm{ME}) / \mathrm{kg}$. At the beginning of each experiment, the animals were divided into nine groups of four animals such that each group within an experiment had the same mean body-weight. One group (the initial control group) was killed and retained for estimation of initial carcass energy. Another group was given the stock diet only and served as the no-drug control group, while the remaining groups were given the stock diet to which was added one of the seven sympathomimetic drugs under investigation. For each drug, the same dose (found to be most effective during the preliminary screening experiments) was administered throughout the whole experimental period. The dose $(\mathrm{mg} / \mathrm{kg}$ diet) for each drug is as follows: ephedrine hydrochloride (Thornton \& Ross (Linthwaite Laboratories); Huddersfield) 1000, methoxyphenamine hydrochloride (Upjohn; Crawley, Sussex) 1000, yohimbine hydrochloride (Sigma; Poole, Dorset) 500, tranylcypromine sulphate (Smith, Kline and French; Welwyn, Herts) 500, amitriptyline hydrochloride (William Warner (Parke Davis); Eastleigh, Hants) 500, iprindole hydrochloride (Wyeth; Maidenhead, Berks) 1000, theophylline (Riker; Loughborough, Leics) 1000.

The authors are aware that this method of dosing is unusual for pharmacological studies but consider it to have many advantages for this type of long-term nutritional investigation. Firstly, it avoids frequent daily handling of animals for injection or oral gavage and this reduces stress. Secondly, it ensures a continuous administration of the drug in association with the diet and increases the likelihood of drug-potentiation of thermogenesis associated with food. Thirdly, it overcomes the problem of deciding whether to dose the animals per $\mathrm{kg}$ body-weight, per $\mathrm{kg}$ to the power of 0.75 or per $\mathrm{kg}$ lean body mass: such considerations are clearly important when dealing with animals of different body size and different degrees of obesity. Finally, pharmacologists might consider this method of stating dose rates when transferring the results of animal metabolic experiments to man, since metabolic rate is more closely related to food intake than to body-weight (Kleiber, 1961; Harwood, 1963; 
Schmidt-Nielson, 1972). It is possible to calculate the doses given in this paper in terms of $\mathrm{mg} / \mathrm{kg}$ body-weight from the data given in the tables but it is our experience that animals given drugs in their food can tolerate higher doses than when the drug is administered acutely by injection or oral gavage and hence comparison with other work may be misleading.

In the mice experiments, the animals in each group were housed together in a cage, while in the rat experiments, the animals were paired per cage. All animals were kept at $25 \pm 1^{\circ}$ during the experiments. Food and water were given ad lib. ; food intake was measured weekly and for all experimental weeks. The energy digestibility, determined over at least 1 week, was used to calculate the ME intake using the formula of Miller \& Payne (1959). The $24 \mathrm{~h}$ oxygen consumption $\left(V_{\mathrm{O}_{2}}\right)$ was measured twice for each group during the second half of each experimental period; the calorimeter apparatus has been described by Boroumand \& Miller (1976).

At the end of each experiment, the animals were killed and all carcasses (including those of the initial controls) were analysed for energy content using the ballistic bomb calorimeter (Miller \& Payne, 1959); total carcass fat was determined by the Soxhlet fat-extraction method (Colowick \& Kaplan, 1957). Carcass protein was calculated using a general formula relating the energy derived from fat with the total energetic value of the carcass and the energy derived from protein (Djazayery et al. 1979). The energy values $(\mathrm{kJ} / \mathrm{g}$ ) for fat and protein used in the equation were 38.6 and 22.7 respectively (Boroumand, 1977). Thus,

$$
\text { protein }(\mathrm{g})=0.044 \text { energy content }(\mathrm{kJ})-1 \cdot 7 \text { fat }(\mathrm{g}) \text {. }
$$

From the values of total ME intake and carcass energy contents, the total heat production was calculated using the following formula:

$$
\text { total heat production }=I-\left(B-B_{0}\right),
$$

where $I$ is the $\mathrm{ME}$ intake, $B$ is the final carcass energy, $B_{\mathrm{o}}$ is the initial carcass energy.

\section{Statistical analysis}

Values for body composition are presented as means with their standard errors and statistical analysis of results was performed using the Student's $t$ test for unpaired values.

\section{RESULTS}

\section{Expt 1. MSG mice}

The body-weights and carcass compositions are shown in Table 2. At the end of the 7-week experiment, the no-drug control group had gained $9.0 \mathrm{~g}$ in body-weight, this being mostly due to a $35 \%$ increase in body fat.

In contrast, methoxyphenamine, yohimbine, tranylcypromine and amitriptyline all caused great reduction in body-weight and in body fat compared with either the no-drug control group or the initial control group. For example, relative to the no-drug control group, methoxyphenamine and tranylcypromine caused losses of 76 and $64 \%$ in body fat respectively, while body fat was reduced by 68 and $52 \%$ respectively when compared with the initial control group. On the other hand, ephedrine, iprindole and theophylline treatments did not cause significant weight reduction, but they prevented the $20 \%$ weight gain that occurred in the no-drug control. Moreover, ephedrine and iprindole caused much loss of total body fat and percentage body fat even when compared with the initial controls. The loss in body fat without a concomitant reduction in body-weight was due to the fact that there was a corresponding gain in body water and body protein in the ephedrine- and iprindole-treated groups. Theophylline treatment, however, had no influence on the carcass 


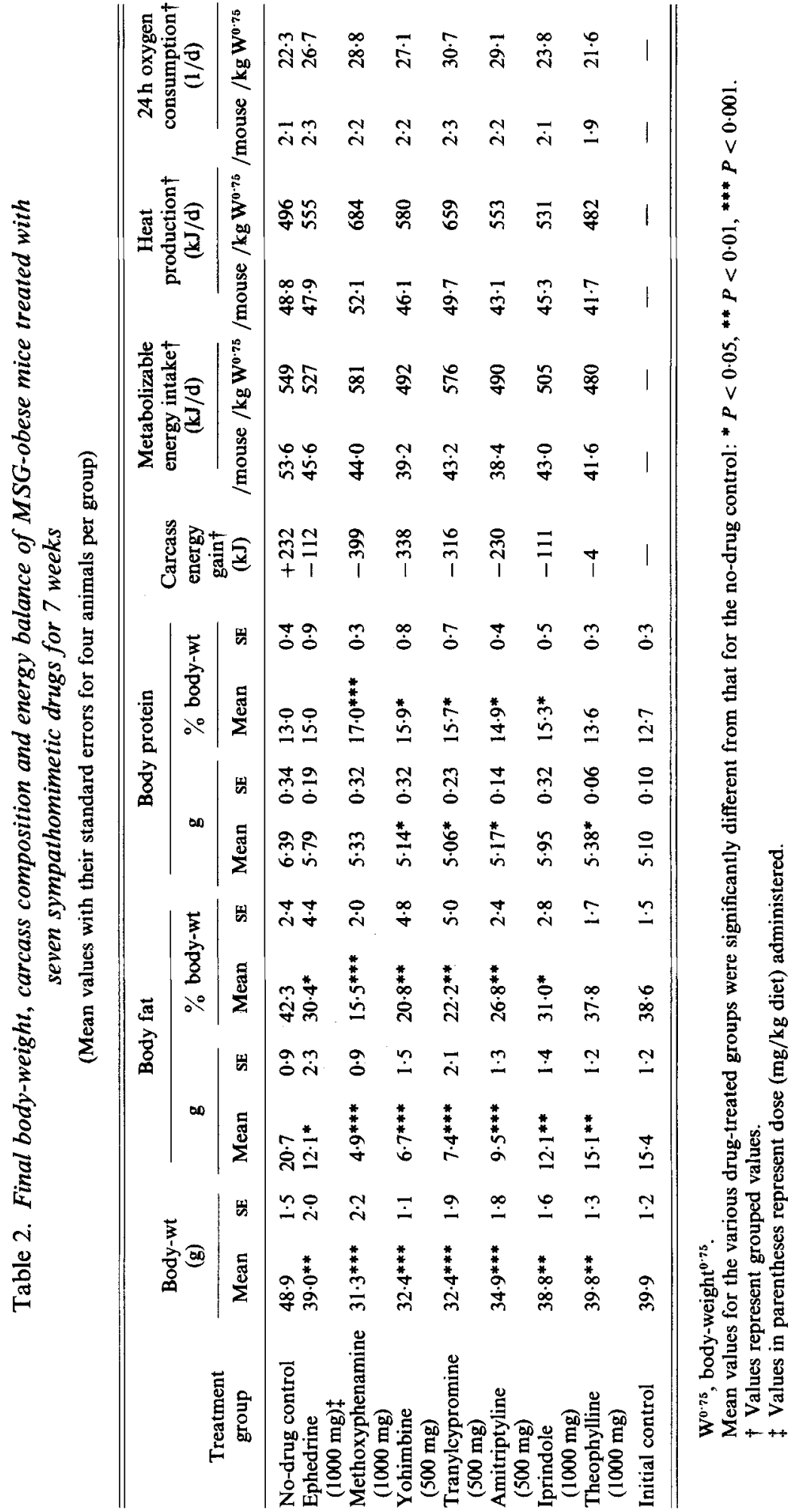


composition which remained similar to that of the initial controls. In all drug-treated groups, the total carcass protein was lower than that of the no-drug control group. However, if a comparison was made with the initial controls, there was no reduction in total body protein. In fact, the proportion of carcass protein in the drug-treated groups was in each case higher than that of the no-drug control group. Thus, with the exception of theophylline, all the other six drugs caused great reduction in body fat without causing loss of body protein.

The values for energy intake show that treatment with the drugs reduced food intake by $20-30 \%$ compared with that of control values. However, when expressed on a per $\mathrm{kg}$ metabolic body size $\left(\mathrm{W}^{0.75}\right)$ basis, the food intakes were similar to that of the controls. Nevertheless, both food intake and energy expenditure values remained lower than those of controls in the theophylline-treated group whichever way the results were expressed. Clearly, theophylline prevented the positive energy balance that occurred in the controls mainly by an anorectic effect. The values for total heat production (estimated by comparative-carcass technique) and $24 \mathrm{~h} V_{\mathrm{O}_{2}}$ (estimated by calorimetric technique) showed that the other six drugs markedly elevated metabolic rate when allowance was made for the smaller body size of these treated groups. For example, the metabolic rate was increased by $29-38 \%$ with methoxyphenamine and tranylcypromine, by $12-30 \%$ with ephedrine, yohimbine and amitriptyline, and by $7 \%$ with iprindole. Moreover, even when expressed per animal, the metabolic rates of most treated groups were higher than that of the much heavier control group: methoxyphenamine and tranylcypromine increased $V_{\mathrm{O}_{2}}$ by 5 and $10 \%$ respectively in animals which weighed about $35 \%$ less than the controls at the time of $V_{\mathrm{O}_{2}}$ measurements.

The thermogenic activities of these six drugs were further illustrated by comparing values with those of the theophylline-treated group. It was found that despite the fact that absolute food intakes (expressed per animal) were similar or higher than those of the theophylline-treated group, they had higher metabolic rates (per animal) and much lower body fat and body energy contents. For instance, both tranylcypromine- and methoxyphenamine-treated groups consumed $6 \%$ more food per animal than the theophylline-treated group, and yet their $V_{\mathrm{O}_{2}}$ values were about $20 \%$ higher and they lost 400 and $316 \mathrm{~kJ}$ respectively, while the theophylline-treated group lost only $4 \mathrm{~kJ}$.

Thus, with the exception of theophylline, the other six drugs brought about a state of negative energy balance in MSG-obese mice mainly by a thermogenic effect.

\section{Expt 2. HPHF mice}

At the end of this experiment, the no-drug control group weighed $5 \%$ more than at the start; this weight gain was due to increases in both body fat and protein with no change in body water (Table 3 ). Compared with the no-drug controls, all seven sympathomimetic drugs caused very marked reductions in body-weight and body fat but had little or no effect on total body protein and water content. Yohimbine caused the most profound reduction in body fat ( $75 \%$ loss), while the other drugs produced between 40 and $60 \%$ reduction in both total fat and percentage body fat. The fact that decreases in body-weight were unaccompanied by reductions in total body protein and water resulted in significantly higher values for percentage body protein and percentage water in all drug-treated groups. When compared with the initial control group, the drug-treated groups also had much lower body fat, whereas body protein was actually higher than in the initial control group.

Energy intakes, if expressed per animal, were similar in all groups, except for a $10 \%$ reduction in the yohimbine-treated group. However, this latter difference was abolished when the smaller body-weight of the yohimbine group was taken into consideration. Thus, food intakes, expressed as a function of body-weight, were either the same or higher than 


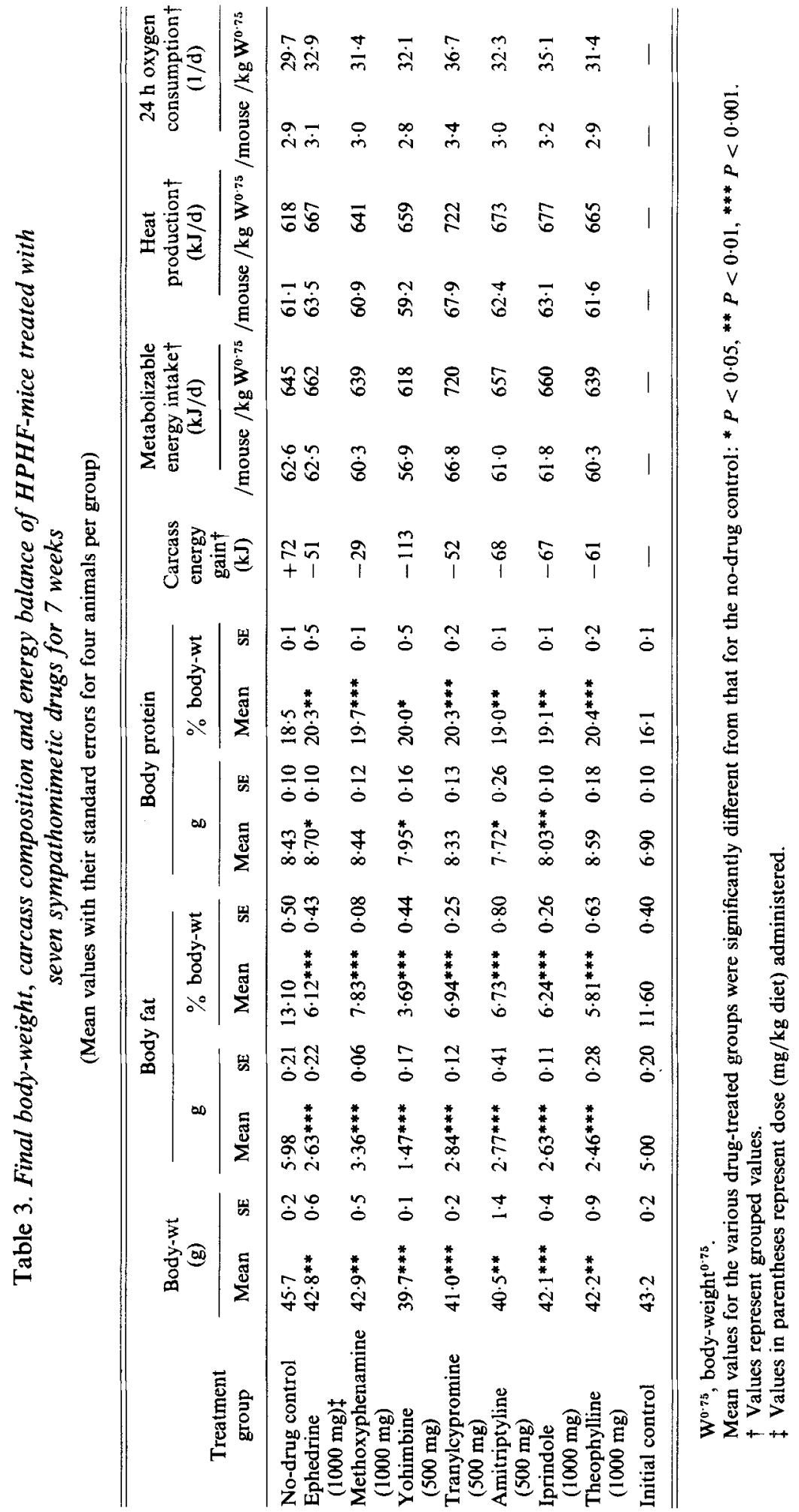


controls. The tranylcypromine-treated group consumed between 7 and $13 \%$ more food, depending on the way in which the results were expressed, and yet this group lost about $50 \%$ body fat when compared with the no-drug control group. In fact, even when expressed in absolute terms, the metabolic rates of some drug-treated groups were found to be higher than those of controls despite their lower body-weight. For example, tranylcypromine, ephedrine and iprindole raised the $24 \mathrm{~h} V_{\mathrm{O}_{2}}$ per animal by 15,7 , and $11 \%$ respectively, while the total heat production was higher by 11,4 , and $3 \%$ respectively than the control values. When total heat production was expressed per metabolic body size, all drugs showed substantial thermogenic effects. These were confirmed by values for $24 \mathrm{~h} V_{\mathrm{O}_{2}}$ which showed that metabolic rates were increased by about $24 \%$ with tranylcypromine, $18 \%$ with iprindole, and between 6 and $9 \%$ with the other drugs.

Thus, in this dietary obese model, all seven sympathomimetic drugs caused negative energy balance by virtue of their thermogenic effects.

\section{Expt 3. (ob/ob) mice}

The body-weights and carcass compositions are shown in Table 4. At the end of the experiment, the no-drug control group had gained $6.6 \mathrm{~g}$ in body-weight, but this was mostly due to an increase in body water, with only a slight increase of $1.0 \mathrm{~g}$ in body fat content and no change in body protein. Consequently, when expressed as a percentage of body-weight, both the body fat and protein values were lower than those of the initial controls.

Only tranylcypromine caused substantial reduction in body-weight with respect to the initial control value. However, when comparisons were made with the no-drug control, all drug treatments (except theophylline) did reduce body-weight, although significant differences were obtained only for tranylcypromine $(P<0.01)$ and methoxyphenamine $(P<0.05)$. Total body fat was reduced by 18 and $28 \%$ in the ephedrine- and tranylcypromine-treated groups respectively, and this was associated with about $13 \%$ less body protein than in the no-drug controls. However, it should be noted that these losses of total body protein were not reflected in changes in the percentage of protein in the carcass. For example, tranylcypromine- and ephedrine-treated groups had similar values for percentage body protein as the no-drug controls. The other drugs had little effect on body fat but, in methoxyphenamine- and theophylline-treated groups, the percentage body fat was elevated, and was significantly higher: about $12 \%$ above control values. The theophyllinetreated group also had increased percentage body protein $(P<0.01)$.

Table 4 shows that, with the exception of theophylline, the other drugs caused $10-20 \%$ reduction in absolute food intake. However, such differences were abolished when food intakes were expressed as $\mathrm{kJ} / \mathrm{kg} \mathrm{W}^{0.75}$. The results for total heat production and $24 \mathrm{~h} V_{\mathrm{O}_{2}}$ revealed that only ephedrine and tranylcypromine elevated metabolic rate substantially by 8 and $10-19 \%$ respectively.

Thus, in the genetic $o b / o b$ obese model, only ephedrine and tranylcypromine were found to have thermogenic activities and to cause substantial loss of body fat.

\section{Expt 4. Lean mice}

Table 5 shows that only the tranylcypromine-treated group showed a significant weight loss compared with the no-drug controls. Surprisingly, the ephedrine-treated animals had an elevated body-weight, although not significantly; this was due to a greater body water retention. Both ephedrine and tranylcypromine treatments reduced body fat content by 14 and $17 \%$ respectively when compared with the no-drug controls. However, comparison of carcass composition with that of initial controls revealed that both these latter drugs reduced fat deposition rather than caused fat losses. Similarly, tranylcypromine treatment caused 
reduction in protein deposition, but the final percentage body protein content was not lower than that of controls. Ephedrine had no effect on either total or percentage body protein. The other drugs did not alter the carcass composition of these lean animals compared with the no-drug controls.

The values for food intake, total heat production and $24 \mathrm{~h} V_{\mathrm{O}_{2}}$ are also shown in Table 5. It is noticed that the ephedrine-treated animals consumed about $3 \%$ more food than the controls but this increase in intake was over-compensated by a $6 \%$ increase in total heat production, such that this group gained less body energy than the controls. Tranylcyprominetreated animals, on the other hand, had similar absolute energy intake and total heat production; however, if the results were expressed as a function of metabolic body size $\left(\mathrm{W}^{0 \cdot 75}\right)$ it was found that the food intake and heat production were increased by about 2 and $4 \%$ respectively. Measurements of $24 \mathrm{~h} V_{\mathrm{O}_{2}}$, however, showed more marked increases in metabolic rate in both tranylcypromine- and ephedrine-treated groups: absolute $V_{\mathrm{O}_{2}}$ was higher by 9 and $13 \%$ respectively while $V_{\mathrm{O}_{2}} / \mathrm{W}^{0 \cdot 75}$ was elevated by 13 and $10 \%$ respectively.

In the cases of theophylline- and iprindole-treated animals, both the absolute food intake and heat production were slightly elevated (by 3-4\%), while in the methoxyphenamine- and yohimbine-treated groups they were reduced (by 6-8\%). However, the body composition and body energy content of these treated groups remained similar to those of the no-drug control group, and therefore suggest that these four drugs had little influence on the net energy balance of these lean mice.

Thus, with the lean mice, only tranylcypromine and ephedrine caused substantial thermogenic effects that led to reduced body fat deposition.

\section{Expt 5. Zucker fa/fa rats}

The no-drug control group gained $8 \%$ more weight during the course of the 9-week experiment. However, like the $o b / o b$ mice (Expt 3), this increase in body-weight was largely due to an increase in body water; body fat was only slightly increased while body protein remained unaltered (Table 6). All seven sympathomimetic drugs caused much loss in both total and percentage body fat. These effects were more marked with ephedrine, tranylcypromine and iprindole: these drugs caused total body fat to be reduced to about one-half and percentage body fat to two-thirds that of control values. The remaining drugs also reduced body fat by $25-35 \%$ of control values. Total body protein of the animals treated with ephedrine, tranylcypromine and iprindole was similar to that of the no-drug control group.

The food intake per animal was reduced in all groups when compared with controls. This effect was most pronounced with groups treated with tranylcypromine and iprindole; the food consumption (per animal) was only two-thirds that of the controls. When food intake was expressed per $\mathrm{kg} \mathrm{W}^{\mathbf{0} 75}$, the difference in food intake was abolished in most drug-treated groups; but food intakes per $\mathrm{kg} \mathrm{W}^{0.75}$ of the tranylcypromine- and iprindole-treated animals were still $25 \%$ less than that of the controls.

On the other hand, values for metabolic rate showed that all these seven drugs possess thermogenic activities. In fact, the $24 \mathrm{~h} V_{\mathrm{O}_{2}}$ results indicate that if the smaller metabolic body size of the treated animals compared with the no-drug controls is taken into account, then the metabolic rate was increased by $18-26 \%$ with ephedrine, tranylcypromine and methoxyphenamine, and by $6-14 \%$ with the remaining drugs. Similarly, total heat production (per $\mathrm{kg} \mathrm{W}^{0.75}$ ) was higher in all drug-treated groups: ephedrine and tranylcypromine caused a $30 \%$ increase in heat production, while the other drugs elevated the metabolic rate by $15-20 \%$ above that of the control group. Furthermore, despite the smaller body-weights compared with the control group during much of the experimental period, the total heat production expressed in abolute terms was higher by $5-13 \%$ in those groups treated with ephedrine, methoxyphenamine, yohimbine, amitriptyline and theophylline. 


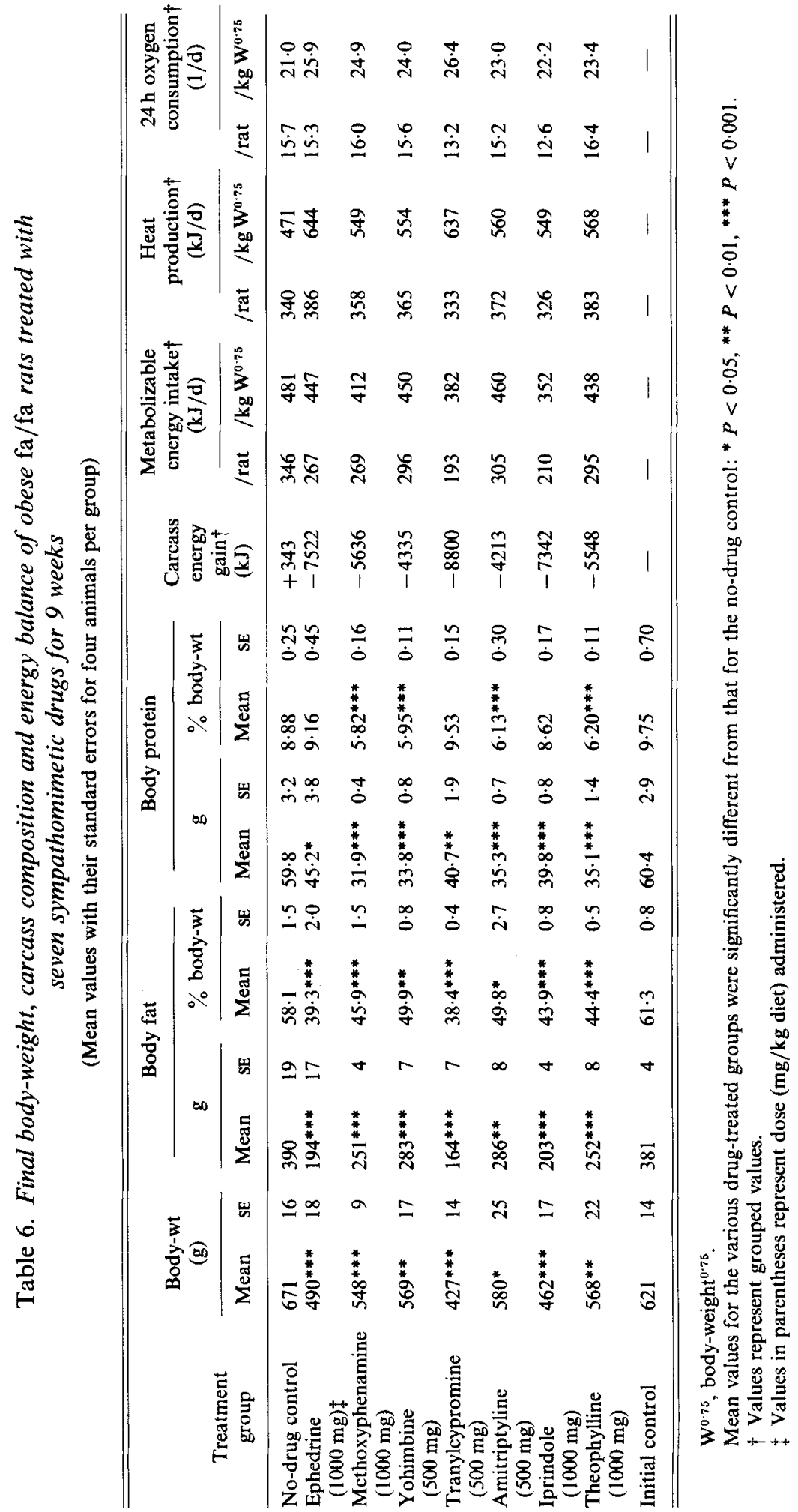




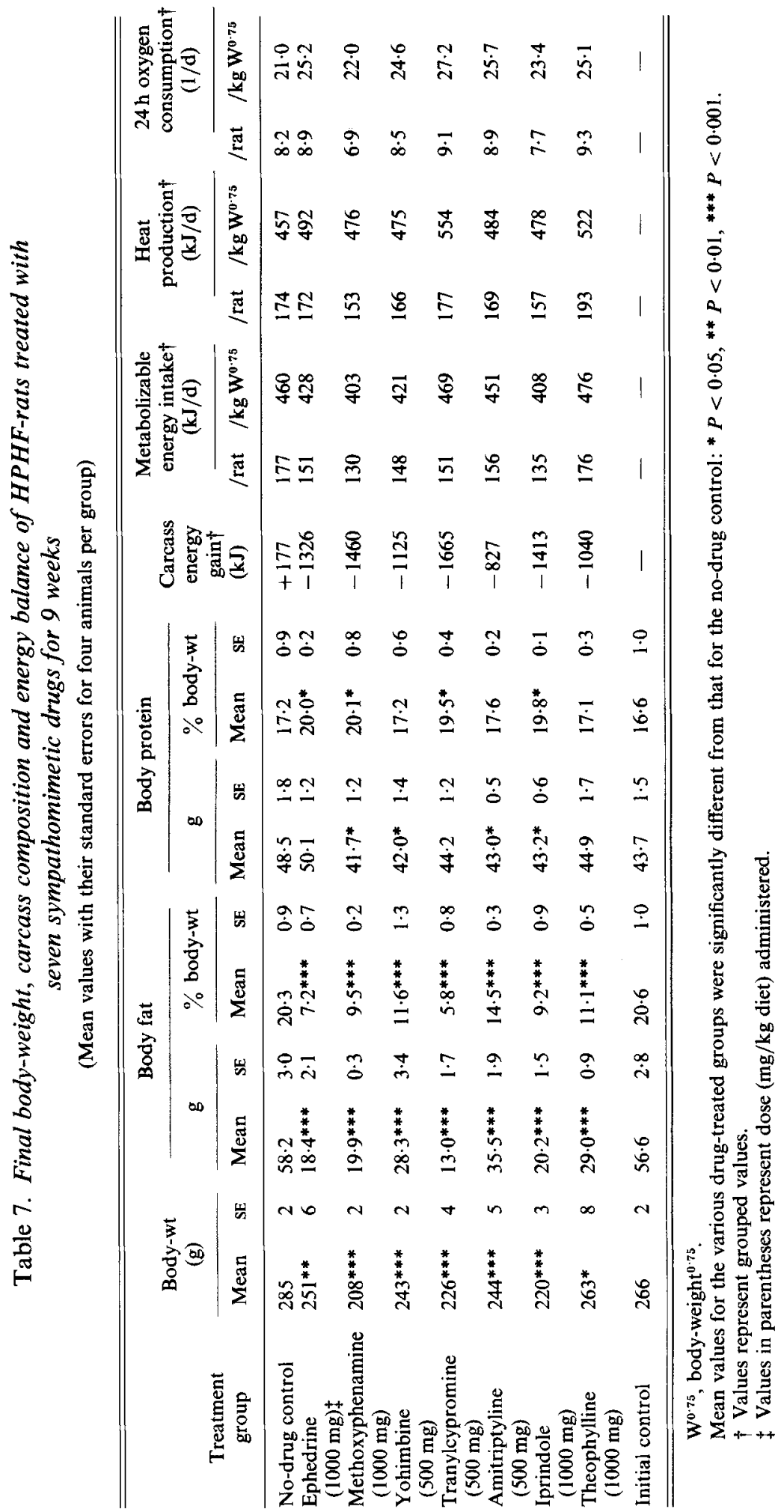


Thus, all seven sympathomimetic drugs showed thermogenic effects in this geneticallyobese model although, in the case of treatment with iprindole and tranylcypromine, anorectic effects were observed, particularly during the first 2-3 weeks of the experiment. Nevertheless, over several weeks the thermogenic effects of these drugs played a more important role in causing fat losses than any initial anorectic effects.

\section{Expt 6. HPHF rats}

The body-weights and carcass compositions are shown in Table 7. The 7\% increase in body-weight of the no-drug control group relative to the initial controls resulted from increases in body fat, protein and water, such that the percentages of the latter body components were similar in both the final and initial control groups. All drug-treated groups lost body-weight compared with the no-drug controls. With the exception of theophylline, all drug-treated groups had significantly lower body-weights at the end of the experiment than at the start of the experiment. Both the total body fat and the percentage body fat were markedly reduced in all drug-treated groups compared with the no-drug controls; this effect was most pronounced with tranylcypromine $(78 \%$ loss), followed by ephedrine, methoxyphenamine and iprindole $(65 \%$ loss), while the yohimbine and theophylline treatments caused $50 \%$ loss of body fat. Ephedrine treatment had no effect on total body protein. The other drugs, on the other hand, prevented deposition of protein although they did not cause loss of protein compared with the initial controls. Thus all seven drugs caused marked reductions in body fat without causing loss of body protein.

The values for food intake indicate that, with the exception of the theophylline-treated animals, all the other drug-treated groups consumed between 12 and $27 \%$ less food (per animal) than the controls. However, when due allowances were made for their smaller body-weights, many of the differences in food intake were abolished. The values for $24 \mathrm{~h}$ $V_{\mathrm{O}_{2}}$ (per rat) indicate that metabolic rates were elevated by about $4-13 \%$ in the drug-treated groups, except those given methoxyphenamine and iprindole. However, when expressed as a function of body size, both the $24 \mathrm{~h} V_{\mathrm{O}_{2}}$ and the total heat production were elevated with all drugs. For example, $V_{\mathrm{O}_{2}}$, expressed per metabolic body size, was increased by $5 \%$ with methoxyphenamine, by about $30 \%$ with tranylcypromine and by $10-20 \%$ with the remaining drugs.

Thus, in this dietary model too, the seven sympathomimetic drugs showed thermogenic activities.

\section{DISCUSSION}

It is well known that there are marked differences between the various models of animal obesity (Miller, 1979). Since it is difficult in the present state of knowledge to say which is the most relevant model of obesity and since human obesity most probably does not have a single aetiology, it seemed better to work with a broad selection of obese models in the search for insight into the involvement of a possible reduced sympathetic nervous system activity underlying obesity.

The present studies indicate that elevation of thermogenesis and fat losses can be induced in different models of animal obesity and to a lesser extent in lean mice by drugs known to act at various points along the line of the sympathetic control of noradrenaline action. Moreover, in support of previous investigations by Massoudi et al. (1983), the present work also shows that important differences are revealed when the animal models are given drugs. Some of the major differences are discussed later (p. 193). However, in order to simplify the understanding of the whole study, the effects of each of the seven drugs used on each of the models have been expressed relative to the appropriate no-drug control animals. Such values are presented in Table 8 and include values for the effects of each drug on final body-weight $(\mathrm{g})$, carcass fat $(\mathrm{g})$, and protein $(\mathrm{g})$, total ME intake $\left(\mathrm{kJ} / \mathrm{kg} \mathrm{W}^{0.75}\right)$, total heat 


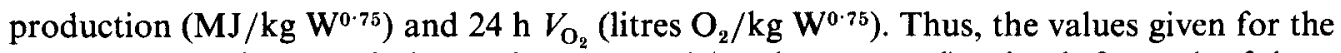
treated MSG mice are relative to the untreated (no-drug control) animals for each of these factors.

\section{Hypothalamic obesity}

Table 8 indicates that, with the exception of theophylline, all the other six sympathomimetic drugs caused marked elevation in metabolic rate and were effective in causing a great reduction in body fat. Such effects were accompanied by little reduction in body protein and the food intake was only minimally affected. The values for both the total heat production and $24 \mathrm{~h} V_{\mathrm{O}_{2}}$ indicate that methoxyphenamine and tranylcypromine were most potent in increasing thermogenesis in this model without reducing food intake: both drugs elevated metabolic rate by $30 \%$ or more. Although yohimbine and amitriptyline caused approximately $10 \%$ reduction in food intake, they also showed similar potent thermogenic activities to ephedrine and increased total heat production by $12-17 \%$.

This experiment therefore confirms the results of the screening procedure adopted in the preliminary experiments for the detection of drugs (Table 1) with potential thermogenic properties (Dulloo, 1982). It is therefore quite likely that some other drugs which were not chosen for the main experiment, but which showed some thermogenic potential, may also prove to be capable of increasing metabolic rate if fully investigated. In the case of theophylline, the preliminary results suggested that it has potential thermogenic effects but the complete energy-balance study reported here failed to show any thermogenic activity. This discrepancy could be due to the fact that much of the weight loss that occurred in the preliminary screening experiment was due to loss of body water. Such findings therefore lend support to the view that changes in body-weight may not necessarily be due to changes in body energy stores and that long-term energy-balance studies are necessary to support any claim of thermogenic potential.

\section{Genetic obesity}

Table 8 shows that all seven drugs produced marked reductions in body-weight and fat in the Zucker $f a / f a$ rats, but only those animals on ephedrine and tranylcypromine were thermogenically active in the $o b / o b$ animals. Moreover, although tranylcypromine was more potent than ephedrine in raising metabolic rate and causing fat losses in the $o b / o b$ mice, these two drugs were of equal potency for such effects in the Zucker $f a / f a$ rats.

Thus, although there are similarities between these two genetic autosomal recessive models of obesity, there are also marked differences in their responses to these drugs.

\section{Dietary-induced obesity}

Since the same technique to produce obesity was used in both the CFLP mice and the Hooded rats, it may be expected that these two dietary models of obesity would respond in a similar way to these drugs. Certainly, a number of similarities are apparent; for example, in each of these models, all seven drugs caused elevation in metabolic rate and brought about much reduction in body-weight and body fat, with little change in body protein. Furthermore, in both these models, tranylcypromine was found to be the most potent drug in raising heat production, whereas methoxyphenamine was least thermogenically effective.

However, Table 8 also shows that there are several differences in the response of these two models to the drugs. For instance, tranylcypromine treatment caused an $11 \%$ increase in food intake of the dietary obese mice, but not in the rat model. On the other hand, methoxyphenamine and iprindole caused a $10 \%$ reduction in food intake of the treated rats, but not of the treated mice. Differences in thermogenic potency of some drugs were also apparent: iprindole had greater thermogenic effects in the mice than in the rats; conversely, theophylline produced a more marked elevation of metabolic rate in the rat model than in the mouse model. 
Table 8. Ratio of drug-treated group: no-drug control group for body-weight, carcass fat and protein, food intake, total heat production and $24 \mathrm{~h}$ oxygen consumption of groups of animals given seven sympathomimetic drugs

\begin{tabular}{|c|c|c|c|c|c|c|c|}
\hline \multirow{2}{*}{$\begin{array}{l}\text { Aetiology of obesity... } \\
\text { Animal model... } \\
\text { Drug treatment }\end{array}$} & & \multirow{2}{*}{$\begin{array}{c}\text { Hypothalamic } \\
\text { obesity } \\
\text { Mice }\end{array}$} & \multicolumn{2}{|c|}{ Dietary obesity } & \multicolumn{2}{|c|}{ Genetic obesity } & \multirow[b]{2}{*}{$\begin{array}{l}\text { Lean } \\
\text { mice }\end{array}$} \\
\hline & & & Mice & Rats & $\begin{array}{c}o b / o b \\
\text { mice }\end{array}$ & $\begin{array}{c}f a / f a \\
\text { rats }\end{array}$ & \\
\hline Ephedrine & $\begin{array}{l}\text { Body-wt } \\
\text { Fat } \\
\text { Protein } \\
\text { ME intake } \\
\text { Heat production } \\
24 \mathrm{~h} V_{\mathrm{O}_{2}}\end{array}$ & $\begin{array}{l}0.80 \\
0.58 \\
0.91 \\
0.96 \\
1 \cdot 12 \\
1 \cdot 20\end{array}$ & $\begin{array}{l}0.94 \\
0.44 \\
1.03 \\
1.03 \\
1.08 \\
1 \cdot 11\end{array}$ & $\begin{array}{l}0.88 \\
0.32 \\
1.03 \\
0.93 \\
1.08 \\
1.20\end{array}$ & $\begin{array}{l}0.89 \\
0.82 \\
0.88 \\
0.99 \\
1.07 \\
1.09\end{array}$ & $\begin{array}{l}0.73 \\
0.50 \\
0.76 \\
0.93 \\
1.36 \\
1.23\end{array}$ & $\begin{array}{l}1.02 \\
0.86 \\
1 \cdot 04 \\
1 \cdot 03 \\
1 \cdot 06 \\
1 \cdot 10\end{array}$ \\
\hline Methoxyphenamine & $\begin{array}{l}\text { Body-wt } \\
\text { Fat } \\
\text { Protein } \\
\text { ME intake } \\
\text { Heat production } \\
24 \mathrm{~h} V_{\mathrm{O}_{3}}\end{array}$ & $\begin{array}{l}0.64 \\
0 \cdot 24 \\
0 \cdot 83 \\
1 \cdot 06 \\
1 \cdot 38 \\
1 \cdot 29\end{array}$ & $\begin{array}{l}0.94 \\
0.56 \\
1.00 \\
0.99 \\
1.04 \\
1.06\end{array}$ & $\begin{array}{l}0.73 \\
0.34 \\
0.86 \\
0.88 \\
1.04 \\
1.05\end{array}$ & $\begin{array}{l}0.91 \\
1.04 \\
0.76 \\
0.91 \\
0.92 \\
0.99\end{array}$ & $\begin{array}{l}0.82 \\
0 \cdot 64 \\
0.53 \\
0 \cdot 86 \\
1 \cdot 16 \\
1 \cdot 18\end{array}$ & $\begin{array}{l}1.01 \\
1.03 \\
0.99 \\
0.93 \\
0.92 \\
0.96\end{array}$ \\
\hline Yohimbine & $\begin{array}{l}\text { Body-wt } \\
\text { Fat } \\
\text { Protein } \\
\text { ME intake } \\
\text { Heat production } \\
24 \mathrm{~h} V_{\mathrm{O}_{2}}\end{array}$ & $\begin{array}{l}0.66 \\
0 \cdot 33 \\
0 \cdot 80 \\
0 \cdot 90 \\
1 \cdot 17 \\
1 \cdot 22\end{array}$ & $\begin{array}{l}0.87 \\
0.24 \\
0.94 \\
0.96 \\
1.07 \\
1.08\end{array}$ & $\begin{array}{l}0.85 \\
0.49 \\
0.87 \\
0.92 \\
1.04 \\
1.17\end{array}$ & $\begin{array}{l}0.92 \\
0.95 \\
0.91 \\
0.91 \\
0.94 \\
0.98\end{array}$ & $\begin{array}{l}0.85 \\
0 \cdot 73 \\
0 \cdot 57 \\
0.94 \\
1 \cdot 18 \\
1 \cdot 14\end{array}$ & $\begin{array}{l}1.00 \\
1.20 \\
0.90 \\
0.94 \\
0.93 \\
0.95\end{array}$ \\
\hline Tranylcypromine & $\begin{array}{l}\text { Body-wt } \\
\text { Fat } \\
\text { Protein } \\
\text { ME intake } \\
\text { Heat production } \\
24 \mathrm{~h} V_{\mathrm{O}_{2}}\end{array}$ & $\begin{array}{l}0.66 \\
0.36 \\
0.79 \\
1.05 \\
1.33 \\
1.38\end{array}$ & $\begin{array}{l}0.90 \\
0 \cdot 47 \\
0 \cdot 99 \\
1 \cdot 11 \\
1 \cdot 17 \\
1 \cdot 24\end{array}$ & $\begin{array}{l}0.79 \\
0.22 \\
0.91 \\
1 \cdot 02 \\
1 \cdot 21 \\
1 \cdot 30\end{array}$ & $\begin{array}{l}0.83 \\
0.72 \\
0.86 \\
0.98 \\
1 \cdot 10 \\
1.19\end{array}$ & $\begin{array}{l}0.64 \\
0.42 \\
0.68 \\
0 \cdot 79 \\
1 \cdot 35 \\
1 \cdot 26\end{array}$ & $\begin{array}{l}0.94 \\
0 \cdot 83 \\
0.90 \\
1 \cdot 02 \\
1 \cdot 04 \\
1 \cdot 13\end{array}$ \\
\hline Amitriptyline & $\begin{array}{l}\text { Body-wt } \\
\text { Fat } \\
\text { Protein } \\
\text { ME intake } \\
\text { Heat production } \\
24 \mathrm{~h} V_{\mathrm{O}_{2}}\end{array}$ & $\begin{array}{l}0.71 \\
0.46 \\
0.81 \\
0.89 \\
1 \cdot 12 \\
1 \cdot 30\end{array}$ & $\begin{array}{l}0.89 \\
0.46 \\
0.92 \\
1.02 \\
1.09 \\
1.09\end{array}$ & $\begin{array}{l}0.86 \\
0.61 \\
0.89 \\
0.98 \\
1.07 \\
1.22\end{array}$ & $\begin{array}{l}0.93 \\
0.94 \\
1.03 \\
0.92 \\
0.94 \\
1.01\end{array}$ & $\begin{array}{l}0.86 \\
0.73 \\
0.59 \\
0.96 \\
1.18 \\
1.10\end{array}$ & $\begin{array}{l}1.00 \\
1.08 \\
0.98 \\
0.98 \\
0.98 \\
1.01\end{array}$ \\
\hline Iprindole & $\begin{array}{l}\text { Body-wt } \\
\text { Fat } \\
\text { Protein } \\
\text { ME intake } \\
\text { Heat production } \\
24 \mathrm{~h} V_{\mathrm{O}_{2}}\end{array}$ & $\begin{array}{l}0.79 \\
0.58 \\
0.93 \\
0.92 \\
1.07 \\
1.07\end{array}$ & $\begin{array}{l}0.92 \\
0.44 \\
0.95 \\
1 \cdot 02 \\
1 \cdot 10 \\
1 \cdot 18\end{array}$ & $\begin{array}{l}0.77 \\
0.35 \\
0.89 \\
0.89 \\
1.05 \\
1 \cdot 11\end{array}$ & $\begin{array}{l}0.89 \\
0.90 \\
0.80 \\
0.89 \\
0.94 \\
1.00\end{array}$ & $\begin{array}{l}0.69 \\
0.52 \\
0.67 \\
0.73 \\
1 \cdot 16 \\
1.06\end{array}$ & $\begin{array}{l}0 \cdot 98 \\
1 \cdot 10 \\
1 \cdot 01 \\
1 \cdot 03 \\
1 \cdot 03 \\
1 \cdot 01\end{array}$ \\
\hline Theophylline & $\begin{array}{l}\text { Body-wt } \\
\text { Fat } \\
\text { Protein } \\
\text { ME intake } \\
\text { Heat production } \\
24 \text { h } V_{\mathrm{O}_{2}}\end{array}$ & $\begin{array}{l}0.81 \\
0.73 \\
0.84 \\
0.87 \\
0.97 \\
0.97\end{array}$ & $\begin{array}{l}0.92 \\
0.41 \\
1.02 \\
0.99 \\
1.08 \\
1.06\end{array}$ & $\begin{array}{l}0.92 \\
0.50 \\
0.93 \\
1.03 \\
1.14 \\
1.20\end{array}$ & $\begin{array}{l}0.99 \\
1.11 \\
1.24 \\
1.03 \\
0.99 \\
0.98\end{array}$ & $\begin{array}{l}0.85 \\
0.65 \\
0.59 \\
0.91 \\
1.21 \\
1.11\end{array}$ & $\begin{array}{l}1 \cdot 07 \\
1 \cdot 10 \\
1 \cdot 00 \\
1 \cdot 02 \\
1 \cdot 01 \\
1 \cdot 00\end{array}$ \\
\hline
\end{tabular}

ME, metabolizable energy; $V_{\mathrm{O}_{2}}$, oxygen consumption.

\section{Thermogenic effectiveness of the drugs}

These complete energy balance experiments confirmed the thermogenic effects of the drugs in several different models of animal obesity. However, the thermogenic effectiveness of these seven drugs varied considerably among the different types of obesity (Table 8).

The indirectly-acting sympathomimetic amine ephedrine, and the monoamine oxidase 
(EC 1.4.3.4) inhibitor tranylcypromine, were found to be most potent in elevating thermogenesis in all five obese models. The $\beta$-agonist methoxyphenamine and the presynaptic $\alpha_{2}$-antagonist yohimbine, although ineffective in the $o b / o b$ mice, showed substantial thermogenic activities in the hypothalamic MSG and genetic $f a / f a$ models, and also to a lesser extent in the two dietary-obese models. The noradrenaline-uptake blockers, amitriptyline and iprindole, were also without effect in the $o b / o b$ model but showed substantial thermogenic properties in the hypothalamic and dietary and genetic $\mathrm{fa} / \mathrm{fa}$ models. Finally, the phosphodiesterase ( $E C$ 3.1.4.1) inhibitor, theophylline, was ineffective in the hypothalamic and $a b / o b$ animals, but it produced marked elevation of metabolic rate in the two dietary-obese models and also in the genetically-obese $f a / f a$ rats.

In general, the drugs were found to be more effective in the obese than in the lean animals. This is to be expected if obesity is due to a metabolic defect. Thus drugs that would correct the defect in the obese would effectively increase thermogenesis in these animals, whereas they would be of relatively little value in normal lean animals that have no such defective mechanisms. In fact, the existence of a better regulation of body energy stores in the lean animals is supported by the fact that some of the drugs caused alterations in energy expenditure that tended to be opposed by similar alterations in energy intake. Nonetheless, although ephedrine and tranylcypromine caused both the metabolic rate and food intake to increase, the extra food consumed was not enough to compensate for the elevated heat production and the animals lost some fat.

\section{Metabolic basis of obesity}

Human obesity probably does not have a single aetiology, inasmuch that possible disorders of the sympathetic nervous system are many: in addition, there could be peripheral resistance to noradrenaline. Since the thermogenic drugs described here have different modes of action in stimulating the sympathetic nervous system, such drugs could be useful diagnostic tools in establishing the various types.

The results presented here indicate that these sympathomimetic drugs were more effective in raising metabolic rate in obese than in lean animals, and therefore suggest that the metabolic defect in the obese may be attributed to a reduced sympathetic neural activity. Thus the drugs were less capable of further increasing a normal sympathetic tone in the lean but were more effective in increasing a low sympathetic tone in the obese. This point is well illustrated in the case of the MSG-model: drugs that are capable of increasing noradrenaline levels at the sympathetic neuro-effector junctions or of simulating noradrenaline action on cell membrane $\beta$-adrenoreceptors, were effective in causing marked increases in thermogenesis. On the other hand, the inhibition of phosphodiesterase by theophylline did not have much effect because, in the absence of sufficient noradrenaline, such inhibition is unlikely to cause drastic changes in cAMP levels. These results are therefore compatible with a diminished sympathetic tone as being causative of the reduced thermogenesis that occurs in MSG-obesity following hypothalamic lesions.

However, the results with the other models are more complicated. The genetic $f a / f a$ model responded to all drugs, including theophylline. In contrast, phosphodiesterase inhibition was ineffective in the $o b / o b$ model. The latter model also failed to respond to the $\beta$-agonist and $\alpha_{2}$-antagonist, although they responded to ephedrine and the monoamine oxidase inhibitor, tranylcypromine. The seven drugs therefore fail to point out a definite site of defect such as that found in the MSG-obesity model. Nonetheless, the different responses of the genetic models to these drugs lend support to the idea that these two genetic obesities have different aetiologies.

In the case of the dietary-obese models, it is obvious that there are no clear-cut hypothalamic or genetic disorders underlying their reduced thermogenesis. However, it is possible that in animals given such a high-fat diet, the biochemical pathways involved in fat 
metabolism are less energy-wasteful. In fact, it is known that the energy cost of depositing dietary lipid is about half as much as the net energy cost of depositing triglyceride synthesized from carbohydrate (Rothwell \& Stock, 1982). The drugs described here, however, do not specifically demonstrate that a reduced neural release of noradrenaline is causative for the elevated energetic efficiency in these dietary models, since the latter were responsive to all seven drugs.

The original concept of using drugs as tools to establish the site of the metabolic defect in the various models of obesity has not been fully realized. In the MSG-obese model, however, the results are compatible with an insufficiency of sympathetically-released noradrenaline as being causative for the reduced heat production that occurs following hypothalamic lesioning. However, the defective sympathetic nervous system activity in the genetic and dietary models of obesity is more complicated. Nevertheless, the experiments described here show that by interfering at different steps in noradrenaline transmission, it is possible to stimulate sympathetic nervous system activity and to potentiate thermogenesis and body fat losses in different animal models of obesity. There is thus a prima facie case for human clinical trials especially with those drugs which are already in current use (Table 1) and comparatively safe. No pathological changes were observed in the drug-treated animals.

The authors wish to acknowledge the help of Messrs R. Cox and R. Andrews for technical assistance and the British Council and the Africa Educational Trust for financial support.

\section{REFERENCES}

Arch, J. R. S., Ainsworth, A. T. \& Cawthorne, M. A. (1982). Life Sciences 30, 1817-1826.

Boroumand, M. (1977). Nutrition and genetics: a study of obesity and leanness in the rat. PhD Thesis, London University.

Boroumand, M. \& Miller, D. S. (1976). Proceedings of the Nutrition Society 36, 14A.

Colowick, S. P. \& Kaplan, O. (1957). Methods in Enzymology, vol. 3. New York: Academic Press.

Djazayery, A., Miller, D. S. \& Stock, M. J. (1979). Nutrition and Metabolism 23, 357-367.

Dulloo, A. G. (1982). The regulation of energy balance by the sympathetic nervous system: a study of thermogenic drugs in lean and obese rodents. PhD Thesis, London University.

Harwood, P. D. (1963). Science 139, 684-685.

Kleiber, M. (1961). In The Fire of Life. London: John Wiley.

Massoudi, M., Evans, E. \& Miller, D. S. (1983). Annals of Nutrition and Metabolism 27, 26-37.

Massoudi, M. \& Miller, D. S. (1977). Proceedings of the Nutrition Society 36, 135A.

Miller, D. S. (1979). In Non-genetic Models of Obesity, pp. 131-140 [M. F. W. Festing, editor]. London: Macmillan.

Miller, D. S. \& Payne, P. R. (1959). British Journal of Nutrition 13, 501-508.

Morgan, J. B., York, D. A., Wasilewska, A. \& Portman, J. (1982). British Journal of Nutrition 47, 21-32.

Rothwell, N. J. \& Stock, M. J. (1979). Nature 281, 31-35.

Rothwell, N. J. \& Stock, M. J. (1982). British Journal of Nutrition 47, 461-471.

Schmidt-Nielson, K. (1972). In How Animals Work. Cambridge: Cambridge University Press. 